\title{
Surface Morphology and Growth of Anodic Titania Nanotubes Films: Photoelectrochemical Water Splitting Studies
}

\author{
Chin Wei Lai \\ Nanotechnology \& Catalysis Research Centre (NANOCAT), Institute of Postgraduate Studies (IPS), University of Malaya, \\ 3rd Floor, Block A, 50603 Kuala Lumpur, Malaysia \\ Correspondence should be addressed to Chin Wei Lai; cwlai@um.edu.my
}

Received 29 September 2014; Revised 23 November 2014; Accepted 19 June 2015

Academic Editor: Jinmei He

Copyright (C) 2015 Chin Wei Lai. This is an open access article distributed under the Creative Commons Attribution License, which permits unrestricted use, distribution, and reproduction in any medium, provided the original work is properly cited.

Design and development of one-dimensional nanoarchitecture titania (TiO) assemblies have gained significant scientific interest, which have become the most studied material as they exhibit promising functional properties. In the present study, anodic $\mathrm{TiO}_{2}$ films with different surface morphologies can be synthesized in an organic electrolyte of ethylene glycol (EG) by controlling an optimum content of ammonium fluoride $\left(\mathrm{NH}_{4} \mathrm{~F}\right)$ using electrochemical anodization technique. Based on the results obtained, well-aligned and bundle-free $\mathrm{TiO}_{2}$ nanotube arrays with diameter of $100 \mathrm{~nm}$ and length of $8 \mu \mathrm{m}$ were successfully synthesized in EG electrolyte containing $\approx 5 \mathrm{wt} \%$ of $\mathrm{NH}_{4} \mathrm{~F}$ for $1 \mathrm{~h}$ at $60 \mathrm{~V}$. However, formation of nanoporous structure and compact oxide layer would be favored if the content of $\mathrm{NH}_{4} \mathrm{~F}$ was less than $5 \mathrm{wt} \%$. In the photoelectrochemical (PEC) water splitting studies, wellaligned $\mathrm{TiO}_{2}$ nanotubular structure exhibited higher photocurrent density of $\approx 1 \mathrm{~mA} / \mathrm{cm}^{2}$ with photoconversion efficiency of $\approx 2 \%$ as compared to the nanoporous and compact oxide layer due to the higher active surface area for the photon absorption to generate more photo-induced electrons during photoexcitation stage.

\section{Introduction}

At present, one of the crucial steps taken by many countries to aid our mother earth [1-3] and minimizing environmental problems is applying sustainable development [4-8]. It seems that sustainable development to create an alternative clean and renewable energy $[3,5]$ to sustain the present level of population and economic development is a strategic goal of modern society reflecting contemporary demand for economic, social, political, and environmental development $[9,10]$. To date, hydrogen $\left(\mathrm{H}_{2}\right)$ has been established as a potential future energy carrier [7-9] and possibly the best substitute for fossil fuel to secure the future supply of a clean and sustainable energy [11-14]. This probable supply of energy in the future is by trapping the solar energy to split the water into hydrogen and oxygen gases within a PEC water splitting cell [10-16]. The controlled reaction of hydrogen and oxygen gases within a fuel cell will generate electricity [1719]. However, the cost effective generation of $\mathrm{H}_{2}$ with sunlight via water splitting process is a critical breakthrough needed to transition to a renewable energy based hydrogen economy [14-16].

In fact, a suitable candidate as a photoelectrode for $\mathrm{H}_{2}$ production via water splitting process must have three basic criteria as shown below $[7,8]$.

(i) Stability. The semiconductor must be photochemically stable in aqueous solution, in which it will not be photocorroded during the water splitting process.

(ii) Band Gap. The semiconductor must have a band gap of about 1.7-2.0 eV considering the overpotential losses and energy required for water splitting process.

(iii) Energy Level. For spontaneous water splitting process, the oxidation and reduction potential must lie between the valence and conduction band edges of the semiconductor.

Since 1972, PEC water splitting using $\mathrm{TiO}_{2}$ as photoelectrode was successfully reported by Fujishima and Honda [4, 5]. Since then, $\mathrm{TiO}_{2}$ has been extensively used as an efficient 
photoelectrode in PEC water splitting system for $\mathrm{H}_{2}$ generation [11-16] because of its unique characteristics, such as high active surface area, strong oxidation ability, active at room temperature, outstanding charge transport property, and high stability against corrosion [20, 21]. This breakthrough has triggered the subsequent interests in photocatalysis research by scientists and researchers from all over the world on $\mathrm{TiO}_{2}$ and made $\mathrm{TiO}_{2}$ an important component in photocatalysis field $[6,7]$. However, bundling problem (disorder arrangement of nanotube arrays) and weak adherence of the nanotubes on $\mathrm{Ti}$ substrate remains as a great challenge for synthesizing high quality of one-dimensional (1D) $\mathrm{TiO}_{2}$ nanotubes film [12-16]. Thus, considerable efforts have been conducted to the development of more efficient photoanode materials, especially well-aligned and ordered arrangement of $1 \mathrm{D} \mathrm{TiO}_{2}$ nanotubes [20-22]. Nowadays, synthesis of $\mathrm{TiO}_{2}$ nanostructures can be achieved by various approaches, such as sol-gel methods [23-25], hydrothermal synthesis [26-28], and anodization technique $[22,29,30]$. Among all of these methods, electrochemical anodization technique has been seen as an effective and economical way in the formation of well-aligned $\mathrm{TiO}_{2}$ nanotubes [31-34]. Moreover, anodization technique is relatively simple and can be adopted for largescale industrial production for creating self-organized anodic oxides in the form of nanotubular structures with almost perfect vertical alignment.

In order to obtain the right dimensions and morphologies, a controlled synthesis procedure for the production of well-aligned and ordered arrangement of $1 \mathrm{D} \mathrm{TiO}_{2}$ nanotubes must be investigated and optimized [35-37]. In principles, three different morphologies of Ti anodic oxide layer could be achieved via anodization technique, which are compact oxide layer, nanoporous structure, and self-organized nanotube arrays $[38,39]$. The most important point ought to be mentioned is that anodization technique is a versatile technique to form self-organized nanotubular thin film with controllable dimension, such as tubular's diameter, length, and wall thickness [35-40]. Therefore, well understanding regarding the formation of highly ordered and bundle-free nanotubular structure on anodized $\mathrm{Ti}$ surface is important in order to obtain the right dimensions and morphologies in PEC water splitting studies. In this work, a study has been performed to evaluate the morphology of the anodized Ti foil in different contents of $\mathrm{NH}_{4} \mathrm{~F}$ and determine the best morphology for high efficient PEC water splitting performance.

\section{Experimental Procedure}

Ti foil (99.7\% purity) with a thickness of $127 \mu \mathrm{m}$ from STREM Chemicals, USA, was selected in this experimental work. Before the anodization process was conducted, Ti foils were degreased by sonication in ethanol for 30 minutes. Then, $\mathrm{Ti}$ foils were rinsed in deionised water and dried in a nitrogen stream. Next, anodization process was conducted in a twoelectrode configuration bath, where Ti foil served as anode and the platinum foil served as counter electrode. The anodic oxidation was conducted in EG electrolyte containing $5 \mathrm{wt} \%$ of $\mathrm{H}_{2} \mathrm{O}_{2}$ with different amounts of $\mathrm{NH}_{4} \mathrm{~F}$ (1 wt $\%, 3 \mathrm{wt} \%$, and
$5 \mathrm{wt} \%$ ) for 1 hour at a constant potential of $60 \mathrm{~V}$. In the present study, $\mathrm{H}_{2} \mathrm{O}_{2}$ was maintained at $5 \mathrm{wt} \%$ and applied potential was fixed at $60 \mathrm{~V}$ because smooth and highly ordered nanotubes arrays could be synthesized when they are maintained around this value according to our preliminary study [29, 41]. The current density transient was recorded using a computerized Keithley DC Power Supply. The sweep rate was maintained at $1 \mathrm{~V} / \mathrm{min}$. After the anodization process, the anodic samples were cleaned using acetone and dried in nitrogen stream. The as-prepared anodic samples were then annealed for $4 \mathrm{~h}$ at $400^{\circ} \mathrm{C}$ in argon atmosphere. It was anticipated that the formation of the single crystalline anatase phase would result in enhanced PEC performance [37, 42].

The morphologies of the $\mathrm{TiO}_{2}$ nanotubes were characterized through field emission scanning electron microscopy (FESEM) using a Zeiss SUPRA $35 \mathrm{VP}$ at working distances down to $10 \mathrm{~mm}$. To obtain the thickness of the nanotube layer, cross-sectional measurements were carried out on mechanically bent samples. The actual length of the nanotube arrays was fixed on a $45^{\circ}$ sample stage to view the crosssectional morphologies. Then, actual length was determined by dividing the observed length by $\cos 45^{\circ}$. The PEC water splitting properties of the samples were characterized using a three-electrode PEC water splitting cell with $\mathrm{TiO}_{2}$ nanotube arrays as the working photoelectrode, platinum rod as the counter electrode, and saturated calomel electrode (SCE) as the reference electrode. A solution of $1 \mathrm{M} \mathrm{KOH}$ with addition of $1 \mathrm{wt} \%$ of EG was used as the electrolyte in the PEC cell. In this study, ethylene glycol was used as sacrificial agent to reduce electron-hole recombination losses, which could improve the photocurrent density [7]. All three electrodes were connected to a potentiostat ( $\mu$ Autolab III). A $150 \mathrm{~W}$ xenon lamp (Zolix LSP-X150) with an intensity of $800 \mathrm{~W} / \mathrm{m}^{2}$ was used to produce a largely continuous and uniform spectrum. The light was transmitted by the quartz glass as the xenon lamp shone on the working electrode (photoanode). The xenon lamp was switched on after the three electrodes were connected to the potentiostat and the photocurrent was measured during the voltage sweeping $(5 \mathrm{mV} / \mathrm{s})$.

\section{Results and Discussion}

An optimum content of $\mathrm{NH}_{4} \mathrm{~F}$ has significant influence on the morphology of anodic $\mathrm{TiO}_{2}$ nanotubes film. Figure 1 shows FESEM images of the surface of the anodized Ti foils formed in EG electrolyte containing $5 \mathrm{wt} \%$ of $\mathrm{H}_{2} \mathrm{O}_{2}$ with different contents of $\mathrm{NH}_{4} \mathrm{~F}$ from $1 \mathrm{wt} \%$ to $5 \mathrm{wt} \%$. The insets are the cross-sectional morphology of the oxide layers. From those FESEM images, the morphology of the $\mathrm{Ti}$ anodic oxides was dependent on the contents of $\mathrm{NH}_{4} \mathrm{~F}$ in the electrolyte. Anodization of $\mathrm{Ti}$ foil in a bath containing $1 \mathrm{wt} \% \mathrm{NH}_{4} \mathrm{~F}$ resulted in a thin $\mathrm{TiO}_{2}$ compact oxide layer with small random pits on the surface of Ti foil as shown in Figure 1(a). The overall thickness of the oxide is approximately $500 \mathrm{~nm}$. This result indicates that a low fluoride $\left(\mathrm{F}^{-}\right)$concentration can only form small pits over the $\mathrm{TiO}_{2}$ foil. The reason is attributed to the inactive chemical dissolution reaction, which is induced by the low content of $\mathrm{F}^{-}$ions. 


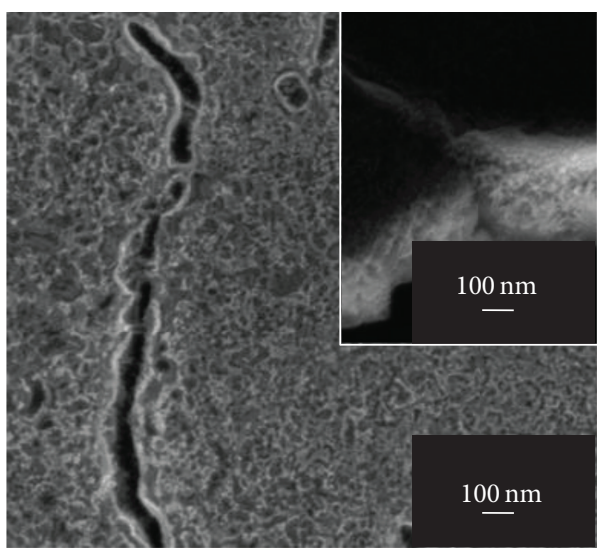

(a)

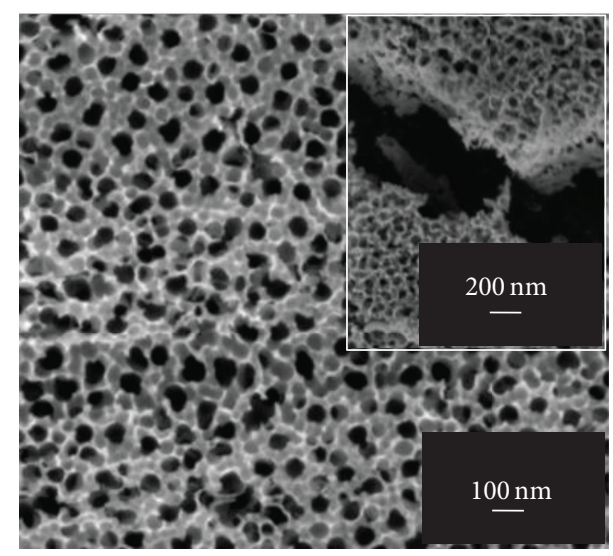

(b)

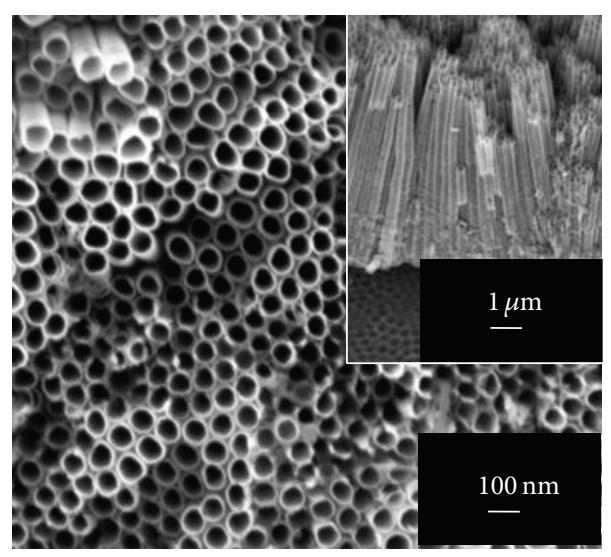

(c)

FIGURE 1: FESEM images of the $\mathrm{TiO}_{2}$ anodic oxide film anodized at $60 \mathrm{~V}$ for $1 \mathrm{~h}$ in EG electrolyte containing $5 \mathrm{wt} \%$ of $\mathrm{H}_{2} \mathrm{O}_{2}$ and different contents of $\mathrm{NH}_{4} \mathrm{~F}$, (a) $1 \mathrm{wt} \%$, (b) $3 \mathrm{wt} \%$, and (c) $5 \mathrm{wt} \%$.

When the amount of $\mathrm{NH}_{4} \mathrm{~F}$ in the electrolyte was increased to $3 \mathrm{wt} \%$, Ti surface contained irregular features and a porous oxide instead of ordered nanopores was observed (Figure 1(b)). The irregular pore sizes are in the range of $25 \mathrm{~nm}-100 \mathrm{~nm}$ and the thickness of this porous oxide layer is approximately $800 \mathrm{~nm}$. The insufficient $\mathrm{F}^{-}$content in the electrolyte probably caused incomplete chemical dissolution and oxidation at the interface between $\mathrm{Ti}$ and the barrier layer. Thus, the irregular features and nanoporous oxide layer formed. For the $5 \mathrm{wt} \% \mathrm{NH}_{4} \mathrm{~F}$, self-organized and well-aligned $\mathrm{TiO}_{2}$ nanotube arrays were successfully synthesized. This indicates that sufficient $\mathrm{F}^{-}$content is able to increase the chemical dissolution reaction during electrochemical anodization process. This led to further acidification to develop a nanotube structure, as shown in Figure 1(c). The $\mathrm{TiO}_{2}$ nanotube arrays with diameters of approximately $100 \mathrm{~nm}$ and lengths of $8 \mu \mathrm{m}$ were formed when the $\mathrm{F}^{-}$ concentration was increased up to $5 \mathrm{wt} \%$. Based on the results obtained, $\mathrm{NH}_{4} \mathrm{~F}$ plays an important role in the formation of the nanotubular structure of $\mathrm{Ti}$ anodic oxide films and an optimum $\mathrm{F}^{-}$content was identified as $\approx 5 \mathrm{wt} \%$ in the EG electrolyte in order to synthesize well-aligned nanotube arrays.
A simple schematic illustration explaining the $\mathrm{TiO}_{2}$ nanotube arrays formation is exhibited in Figure 2. First of all, an oxide layer was formed on Ti surface and then turned into $\mathrm{TiO}_{2}$ due to the electrochemical oxidation process $[43,44]$. In the presence of $\mathrm{F}^{-}$ions, the oxide layer dissolves locally and small pits are formed on the oxide layer (Figure 2(a)). These random pits react with the $\mathrm{F}^{-}$ions to produce $\left[\mathrm{TiF}_{6}\right]^{2-}$ complex ions as shown in the following [43-45]:

$$
\mathrm{TiO}_{2}+4 \mathrm{H}^{+}+6 \mathrm{~F}^{-} \longrightarrow\left[\mathrm{TiF}_{6}\right]^{2-}+2 \mathrm{H}_{2} \mathrm{O}
$$

The porous structure is formed as a result of the localized chemical dissolution of the oxide by $\left[\mathrm{TiF}_{6}\right]^{2-}$ complex ions during electrochemical anodization process (Figure 2(b)) [34]. The chemical dissolution reduces the thickness of the oxide layers and allows electrochemical etching process to continue at the bottom of the pits $[44,46]$. Meanwhile, the high applied potential during anodization process will lead to the field-assisted dissolution, where $\mathrm{Ti}$ metal ions $\left(\mathrm{Ti}^{4+}\right)$ dissolve into electrolyte. The growth of pores is due to the competition between electrochemical oxide formation and chemical dissolution by sufficient content of $\mathrm{F}^{-}$ions [43-47]. Finally, the nanotube structure will grow inwards 


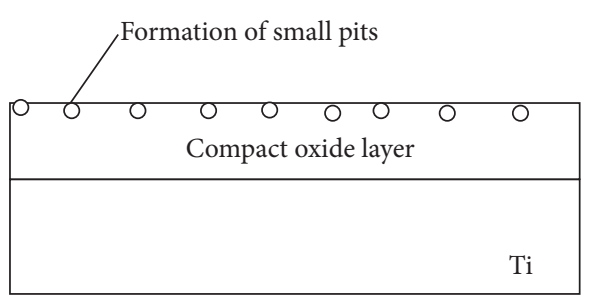

(a)

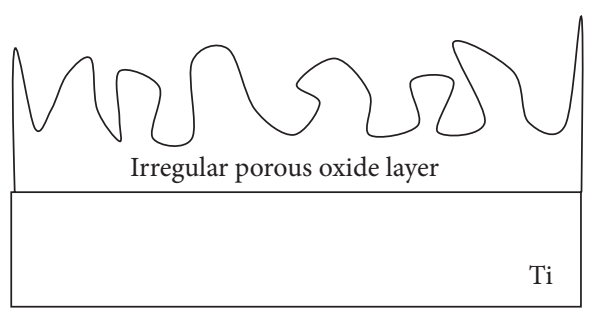

(b)

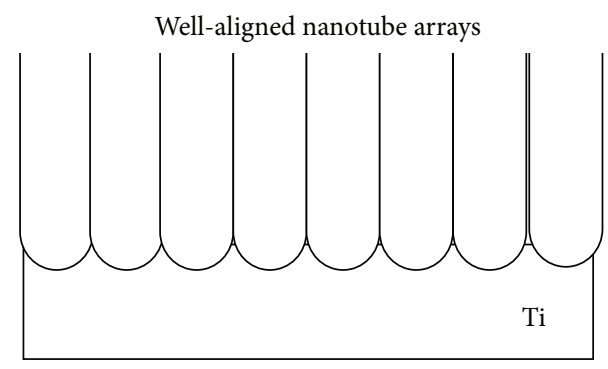

(c)

FIgURE 2: Schematic illustration explaining the $\mathrm{TiO}_{2}$ nanotube arrays formation: (a) growth of compact oxide layer and small pits formation; (b) growth of irregular porous oxide layer; and (c) wellaligned nanotube arrays.

(Figure 2(c)). In summary, formation of $\mathrm{TiO}_{2}$ nanotube arrays in fluorinated electrolyte was the result of three simultaneously occurring processes: (1) field-assisted oxidation of Ti metal to form $\mathrm{TiO}_{2}$, (2) field-assisted dissolution of $\mathrm{Ti}^{4+}$ ions into electrolyte, and (3) chemical dissolution of $\mathrm{Ti}$ and $\mathrm{TiO}_{2}$ in the presence of $\mathrm{F}^{-}$ions $[38,39]$. From the results obtained, it could be concluded that optimum amount of $\mathrm{NH}_{4} \mathrm{~F}$ is one of the important factors for the formation of well-aligned $\mathrm{TiO}_{2}$ nanotubes.

The difference in morphology of the $\mathrm{TiO}_{2}$ nanotube arrays under different amounts of $\mathrm{NH}_{4} \mathrm{~F}$ can be explained by referring to the current density profile, as shown in Figure 3. It was found that current density increased up to $7.8 \mathrm{~mA} / \mathrm{cm}^{2}$ when increasing the $\mathrm{NH}_{4} \mathrm{~F}$ up to $5 \mathrm{wt} \%$ (Figure $3(\mathrm{c})$ ). The reason is attributed to the high diffusivity of the $\mathrm{F}^{-}$ions concentration in the electrolyte, which led to enhanced conductivity of the solution $[48,49]$. The higher current density in the electrolyte indicates that the higher chemical etching process induces by the $\left[\mathrm{TiF}_{6}\right]^{2-}$ complex ions [50].

In order to evaluate the effect of the various morphologies of anodic $\mathrm{TiO}_{2}$ layer on the PEC water splitting performance, the above-discussed samples were used as photoelectrode in

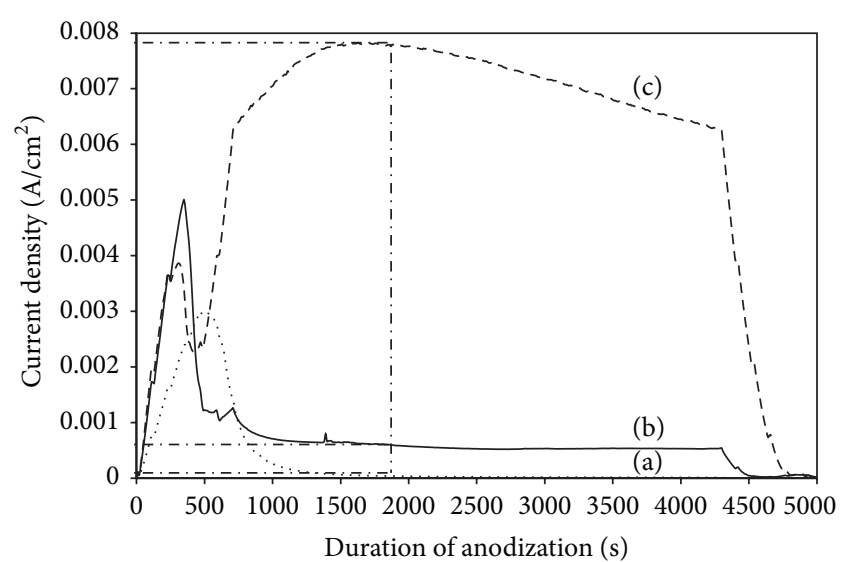

FIGURE 3: The current density-time behavior during the anodization of Ti foils at $60 \mathrm{~V}$ in EG electrolyte containing $5 \mathrm{wt} \% \mathrm{H}_{2} \mathrm{O}_{2}$ and different amounts of $\mathrm{NH}_{4} \mathrm{~F}$, (a) $1 \mathrm{wt} \%$, (b) $3 \mathrm{wt} \%$, and (c) $5 \mathrm{wt} \%$.

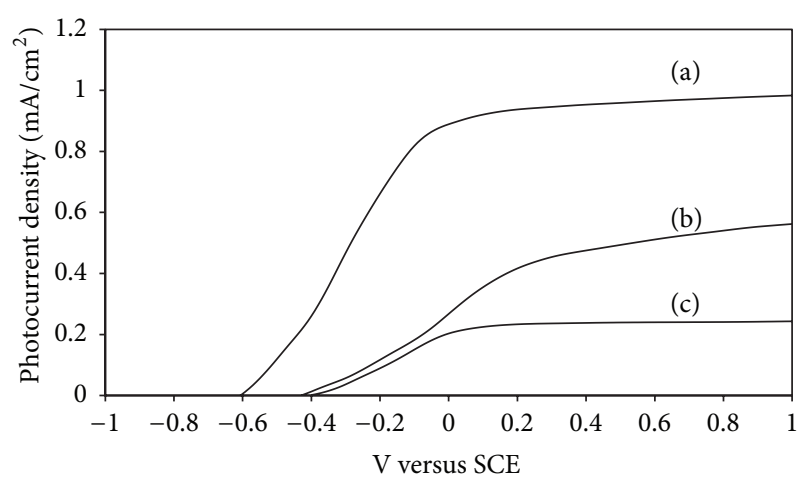

FIGURE 4: The $I-V$ characteristics of different surface morphologies of anodic $\mathrm{TiO}_{2}$ photoanode in $1 \mathrm{M} \mathrm{KOH}$ solution with $1 \mathrm{wt} \%$ of EG, (a) nanotubes, (b) nanoporous, and (c) compact oxide layer.

the PEC water splitting cell. The $I-V$ characteristics of the samples were recorded under illumination by a $150 \mathrm{~W}$ xenon lamp, with a light intensity of approximately $800 \mathrm{~W} / \mathrm{m}^{2}$. Based on the $I-V$ characteristic curves, the photocurrent density was increased when the voltage was increased from $-1 \mathrm{~V}$ to $1 \mathrm{~V}$ under solar illumination. A maximum photocurrent density of approximately $1 \mathrm{~mA} / \mathrm{cm}^{2}$ was observed from the anodic $\mathrm{TiO}_{2}$ nanotube arrays as compared to the nanoporous and compact oxide layer as exhibited in Figure 4(a). Meanwhile, the $\mathrm{TiO}_{2}$ nanoporous structure and $\mathrm{TiO}_{2}$ compact oxide layer exhibited decrease of photocurrent densities, which are approximately $0.55 \mathrm{~mA} / \mathrm{cm}^{2}$ (Figure 4(b)) and $0.25 \mathrm{~mA} / \mathrm{cm}^{2}$ (Figure 4(c)), respectively.

$\mathrm{TiO}_{2}$ nanotube arrays exhibited higher photocurrent density among the samples. The reason is mainly attributed to the larger specific surface area. It is noteworthy to point out that larger specific surface area of well-aligned nanotube arrays can greatly increase the density of active sites available for the photon absorption to generate more photoinduced electrons. The highly ordered, vertically oriented tubular structure is suitable for a high degree of electrons mobility along the tube axis and perpendicular to the $\mathrm{Ti}$ 
substrate, which will greatly reduce interface recombination. As a matter of fact, nanotubular structure offers a preferred dimensionally to the $\mathrm{TiO}_{2}$ back contact, which can improve the transportation of charge carriers due to the less grain boundaries in the one-dimensional nanotube arrays system $[16,35,36,38,39,42]$. In addition, both sides of the nanotube walls and the entire tube sidewalls can act as large number of reaction sites for chemical reactions to occur and allow more photo-induced electrons generated for the hydrogen reduction process during illumination. The larger active surface area proximal to the electrolyte solution enhances the generation of photo-induced electrons from nanotube arrays towards to the back contact of the $\mathrm{TiO}_{2}$ and eventually these photo-induced electrons move to counter electrode (platinum electrode) through the external circuit where they reduce $\mathrm{H}^{+}$ions creating $\mathrm{H}_{2}$ molecules $\left(2 \mathrm{H}^{+}+2 \mathrm{e}^{-} \rightarrow \mathrm{H}_{2}\right)$ under external bias [51, 52]. This statement was further confirmed by the more negative values of photopotential for the $\mathrm{TiO}_{2}$ nanotube arrays $(-0.65 \mathrm{~V})$ compared to $\mathrm{TiO}_{2}$ nanoporous structure $(-0.45 \mathrm{~V})$ and $\mathrm{TiO}_{2}$ oxide layer $(-0.4 \mathrm{~V})$ as shown in Figure 4 . The more negative values of photopotential or open circuit potential indicated that more photo-induced electrons were generated from valence band to the conduction band when the terminal was left open (no bias voltage was applied).

The drawback of the used irregular nanoporous $\mathrm{TiO}_{2}$ structure in PEC studies is most probably due to the numerous defect sites and trapping sites, which results in more recombination losses of charge carriers and reduces the photo-induced collection at the $\mathrm{TiO}_{2}$ back contact [53]. Thus, the photocurrent density was decreasing significantly. On the other hand, the use of $\mathrm{TiO}_{2}$ compact oxide layer showed the lowest photocurrent density among the samples. The compact oxide layer generally will have less specific surface area compared to the nanotubular and nanoporous structure. Thus, the number of photo-induced electrons generated from the photoelectrode will significantly reduce. Based on the results obtained, it is crucial to maximize the specific surface area of $\mathrm{TiO}_{2}$ photoelectrode in the PEC water splitting studies.

Next, the $\mathrm{TiO}_{2}$ response with different surface morphologies towards the interruption of light was studied with a potentiostatic (photocurrent density versus time) at a fix bias voltage of $0.6 \mathrm{~V}$. The photocurrent density of the samples was measured and plotted in Figure 5. All samples showed good photoresponses under light pulse illumination. The photo-induced electrons can effectively transfer from $\mathrm{TiO}_{2}$ photoelectrode to counter electrode and eventually generate the photocurrent response during illumination. The photocurrent drastically dropped to approximately $0 \mathrm{~mA}$ under dark conditions. This indicates that $\mathrm{TiO}_{2}$ is a good photo-response semiconductor for the transfer and decay of the photo-induced electrons $[13,42]$. It is noteworthy to point out that the photocurrent reverted back to the original state within a couple of seconds under illumination. This photocurrent pattern was highly reproducible for several onoff cycles. The results from the potentiostatic curves are in good agreement with the results in photocurrent density curves.

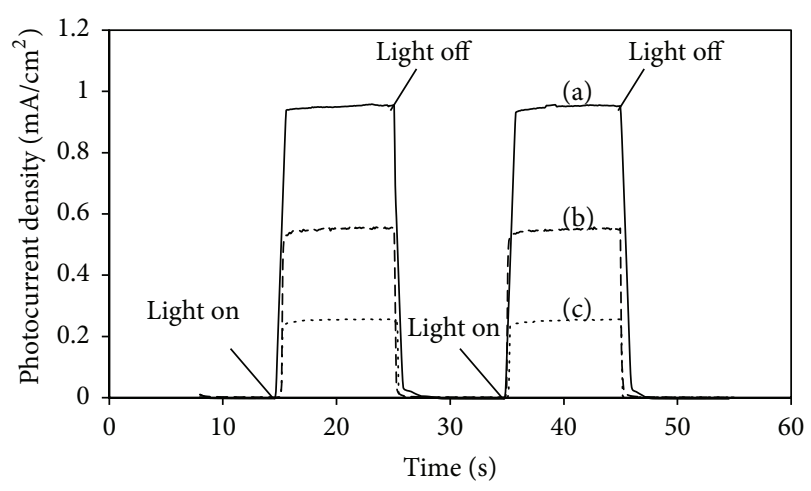

Figure 5: Potentiostatic plot of photocurrent density for different surface morphologies of anodic $\mathrm{TiO}_{2}$ photoanode in $1 \mathrm{M} \mathrm{KOH}$ solution with $1 \mathrm{wt} \%$ of EG under interrupted illumination, (a) nanotubes, (b) nanoporous, and (c) compact oxide layer.

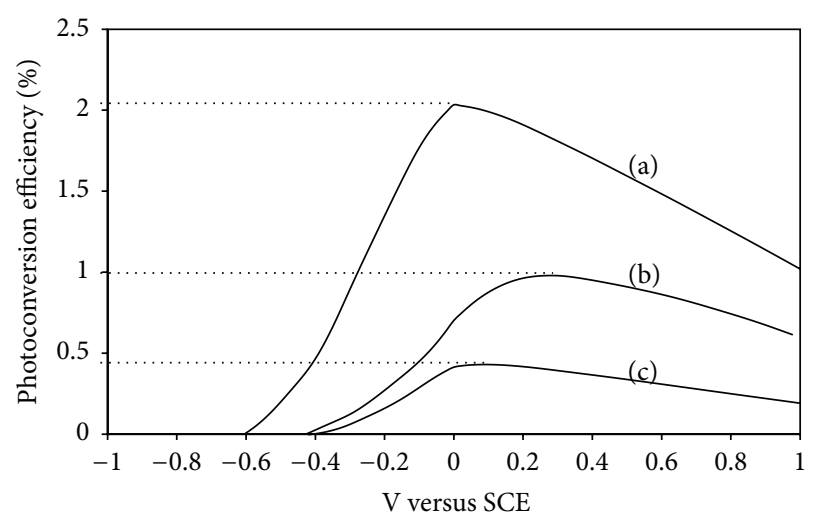

Figure 6: Photoconversion efficiency versus potential applied to the different surface morphologies of anodic $\mathrm{TiO}_{2}$ photoanode (a) nanotubes, (b) nanoporous, and (c) compact oxide layer.

The photoconversion efficiency $(\eta)$ for the water splitting reaction was calculated based on the following equation:

$$
\begin{aligned}
& \eta(\%) \\
& =\left[\frac{\text { total power output }- \text { electrical power output }}{\text { light power input }}\right] \\
& \quad \times 100 \%=j_{p}\left[\frac{E_{\text {rev }}^{0}-\left|E_{\text {app }}\right|}{I_{o}}\right] \times 100,
\end{aligned}
$$

where $j_{p}$ is the photocurrent density $\left(\mathrm{mA} / \mathrm{cm}^{2}\right) ; j_{p} E_{\text {rev }}^{0}$ is the total power output; $j_{p}\left|E_{\text {app }}\right|$ is the electrical power input; $I_{o}$ is the power density of the incident light $\left(\mathrm{mW} / \mathrm{cm}^{2}\right) ; E_{\text {rev }}^{0}$ is the standard reversible potential $(1.23 \mathrm{~V} / \mathrm{SHE}) ; E_{\text {app }}=$ $E_{\text {mean }}-E_{\text {aoc }} ; E_{\text {mean }}$ is the electrode potential (versus SCE) of the working electrode where the photocurrent was measured under illumination; and $E_{\mathrm{aoc}}$ is the potential (versus SCE) of the working electrode at open circuit condition.

The highest visible spectrum efficiency (about 2\%) was obtained from $\mathrm{TiO}_{2}$ nanotube arrays from the photoconversion efficiency curves shown in Figure 6. The decrease in 
photocurrent efficiency was as follows: $1 \%$ and $0.5 \%$, which correspond to nanoporous and compact oxide structure, respectively. These results clearly indicate that the PEC performance is dependent on the specific surface area of the $\mathrm{TiO}_{2}$ anodic film.

\section{Conclusion}

The formation mechanism of self-organized and well-aligned $\mathrm{TiO}_{2}$ nanotube arrays in the fluorinated-based electrolyte was investigated and discussed. The present study demonstrated that bundle-free $\mathrm{TiO}_{2}$ nanotube arrays film was successfully synthesized in EG electrolyte containing $\approx 5 \mathrm{wt} \%$ of $\mathrm{H}_{2} \mathrm{O}_{2}$ and $\approx 5 \mathrm{wt} \%$ of $\mathrm{NH}_{4} \mathrm{~F}$. It is shown that anodic $\mathrm{TiO}_{2}$ synthesized in EG electrolyte containing less than 5 wt $\%$ of $\mathrm{NH}_{4} \mathrm{~F}$ will result in the formation of nanoporous structure and compact oxide layer. The high specific surface area of anodic $\mathrm{TiO}_{2}$ nanotubes generated a good photocurrent response of $1 \mathrm{~mA} / \mathrm{cm}^{2}$ with photoconversion efficiency of $2 \%$. The main reason could be attributed to the better light absorption for the PEC water splitting reaction sites by generating more photo-induced electrons under illumination. In summary, it is crucial to maximize the specific surface area of $\mathrm{TiO}_{2}$ anodic films in order to achieve maximum photocurrent generation and photoconversion efficiency.

\section{Conflict of Interests}

The author declares that there is no conflict of interests regarding the publication of this paper.

\section{Acknowledgments}

This research is supported by High Impact Research Chancellory Grant UM.C/625/1/HIR/228 (J55001-73873) from the University of Malaya. In addition, the author would like to thank University of Malaya for sponsoring this work under MOSTI-ScienceFund (SF003-2015). Lastly, financial supports from PPP grant (PG052-2013 and PG058-2014B) are gratefully acknowledged.

\section{References}

[1] J. A. Turner, "A realizable renewable energy future," Science, vol. 285, no. 5428, pp. 687-689, 1999.

[2] S. E. Gledhill, B. Scott, and B. A. Gregg, "Reviews-energy and the environment special section," Journal of Materials Research, vol. 20, no. 12, pp. 3167-3179, 2005.

[3] M. Jefferson, "Sustainable energy development: performance and prospects," Renewable Energy, vol. 31, no. 5, pp. 571-582, 2006.

[4] M. Kitano, M. Matsuoka, M. Ueshima, and M. Anpo, "Recent developments in titanium oxide-based photocatalysts," Applied Catalysis A: General, vol. 325, no. 1, pp. 1-14, 2007.

[5] A. Fujishima, X. T. Zhang, and D. A. Tryk, " $\mathrm{TiO}_{2}$ photocatalysis and related surface phenomena," Surface Science Reports, vol. 63, no. 12, pp. 515-582, 2008.
[6] K. Yu and J. Chen, "Enhancing solar cell efficiencies through 1D nanostructures," Nanoscale Research Letters, vol. 4, no. 1, pp. 1-10, 2009.

[7] M. Ni, M. K. H. Leung, D. Y. C. Leung, and K. Sumathy, "A review and recent developments in photocatalytic watersplitting using $\mathrm{TiO}_{2}$ for hydrogen production," Renewable and Sustainable Energy Reviews, vol. 11, no. 3, pp. 401-425, 2007.

[8] V. M. Aroutiounian, V. M. Arakelyan, and G. E. Shahnazaryan, "Metal oxide photoelectrodes for hydrogen generation using solar radiation-driven water splitting," Solar Energy, vol. 78, no. 5, pp. 581-590, 2005.

[9] T. K. Tromp, R.-L. Shia, M. Allen, J. M. Eiler, and Y. L. Yung, "Potential environmental impact of a hydrogen economy on the stratosphere," Science, vol. 300, no. 5626, pp. 1740-1742, 2003.

[10] D. A. Tryk, A. Fujishima, and K. Honda, "Recent topics in photoelectrochemistry: achievements and future prospects," Electrochimica Acta, vol. 45, no. 15-16, pp. 2363-2376, 2000.

[11] R. Dholam, N. Patel, M. Adami, and A. Miotello, "Hydrogen production by photocatalytic water-splitting using $\mathrm{Cr}$ - or $\mathrm{Fe}$ doped $\mathrm{TiO}_{2}$ composite thin films photocatalyst," International Journal of Hydrogen Energy, vol. 34, no. 13, pp. 5337-5346, 2009.

[12] Z. Zhang, M. F. Hossain, and T. Takahashi, "Photoelectrochemical water splitting on highly smooth and ordered $\mathrm{TiO}_{2}$ nanotube arrays for hydrogen generation," International Journal of Hydrogen Energy, vol. 35, no. 16, pp. 8528-8535, 2010.

[13] C. W. Lai and S. Sreekantan, "Effect of applied potential on the formation of self-organized $\mathrm{TiO}_{2}$ nanotube arrays and its photoelectrochemical response," Journal of Nanomaterials, vol. 2011, Article ID 142463, 7 pages, 2011.

[14] V. K. Mahajan, S. K. Mohapatra, and M. Misra, "Stability of $\mathrm{TiO}_{2}$ nanotube arrays in photoelectrochemical studies," International Journal of Hydrogen Energy, vol. 33, no. 20, pp. 5369-5374, 2008.

[15] S. K. Mohapatra, K. S. Raja, V. K. Mahajan, and M. Misra, "Efficient photoelectrolysis of water using $\mathrm{TiO}_{2}$ nanotube arrays by minimizing recombination losses with organic additives," Journal of Physical Chemistry C, vol. 112, no. 29, pp. 11007-11012, 2008.

[16] Y. Xie, L. Zhou, and J. Lu, "Photoelectrochemical behavior of titania nanotube array grown on nanocrystalline titanium," Journal of Materials Science, vol. 44, no. 11, pp. 2907-2915, 2009.

[17] M. Grätzel, "Photoelectrochemical cells," Nature, vol. 414, no. 6861, pp. 338-344, 2001.

[18] J. Nowotny, T. Bak, M. K. Nowotny, and L. R. Sheppard, "Titanium dioxide for solar-hydrogen II. Defect chemistry," International Journal of Hydrogen Energy, vol. 32, no. 14, pp. 2630-2643, 2007.

[19] A. Currao, "Photoelectrochemical water splitting," Chimia, vol. 61, no. 12, pp. 815-819, 2007.

[20] W. H. Ryu, C. J. Park, and H. S. Kwon, "A special section on nanocomposites and nanoporous materials," Journal of Nanoscience and Nanotechnology, vol. 10, no. 1, pp. 1-2, 2010.

[21] V. V. Kislyuk and O. P. Dimitriev, "Nanorods and nanotubes for solar cells," Journal of Nanoscience and Nanotechnology, vol. 8, no. 1, pp. 131-148, 2008.

[22] W. Zhu, X. Liu, H. Liu, D. Tong, J. Yang, and J. Peng, "An efficient approach to control the morphology and the adhesion properties of anodized $\mathrm{TiO}_{2}$ nanotube arrays for improved photoconversion efficiency," Electrochimica Acta, vol. 56, no. 6, pp. 2618-2626, 2011.

[23] D.-S. Seo, J.-K. Lee, and H. Kim, "Preparation of nanotubeshaped $\mathrm{TiO}_{2}$ powder," Journal of Crystal Growth, vol. 229, no. 1-4, pp. 428-432, 2001. 
[24] Z.-Y. Yuan and B.-L. Su, "Titanium oxide nanotubes, nanofibers and nanowires," Colloids and Surfaces A: Physicochemical and Engineering Aspects, vol. 241, no. 1-3, pp. 173-183, 2004.

[25] P. Hoyer, K. Nishio, and H. Masuda, "Preparation of regularly structured porous metal membranes with two different hole diameters at the two sides," Thin Solid Films, vol. 286, no. 1-2, pp. 88-91, 1996.

[26] S. Sreekantan and L. C. Wei, "Study on the formation and photocatalytic activity of titanate nanotubes synthesized via hydrothermal method," Journal of Alloys and Compounds, vol. 490, no. 1-2, pp. 436-442, 2010.

[27] M. Zhang, Z. S. Jin, J. W. Zhang et al., "Effect of annealing temperature on morphology, structure and photocatalytic behavior of nanotubed $\mathrm{H}_{2} \mathrm{Ti}_{2} \mathrm{O}_{4}(\mathrm{OH})_{2}$," Journal of Molecular Catalysis A: Chemical, vol. 217, no. 1-2, pp. 203-210, 2004.

[28] T. Kasuga, M. Hiramatsu, A. Hoson, T. Sekino, and K. Niihara, "Titania nanotubes prepared by chemical processing," Advanced Materials, vol. 11, no. 15, pp. 1307-1311, 1999.

[29] S. Sreekantan, L. C. Wei, and Z. Lockman, "Extremely fast growth rate of $\mathrm{TiO}_{2}$ nanotube arrays in electrochemical bath containing $\mathrm{H}_{2} \mathrm{O}_{2}$," Journal of the Electrochemical Society, vol. 158, no. 12, pp. C397-C402, 2011.

[30] Y.-C. Hsiao and Y.-H. Tseng, "Preparation of Pd-containing $\mathrm{TiO}_{2}$ film and its photocatalytic properties," Micro \& Nano Letters, vol. 5, no. 5, pp. 317-320, 2010.

[31] M. Paulose, H. E. Prakasam, O. K. Varghese et al., " $\mathrm{TiO}_{2}$ nanotube arrays of $1000 \mu \mathrm{m}$ length by anodization of titanium foil: Phenol red diffusion," Journal of Physical Chemistry C, vol. 111, no. 41, pp. 14992-14997, 2007.

[32] G. K. Mor, O. K. Varghese, M. Paulose, K. Shankar, and C. A. Grimes, "A review on highly ordered, vertically oriented $\mathrm{TiO}_{2}$ nanotube arrays: fabrication, material properties, and solar energy applications," Solar Energy Materials and Solar Cells, vol. 90, no. 14, pp. 2011-2075, 2006.

[33] J. M. Macak and P. Schmuki, "Anodic growth of self-organized anodic $\mathrm{TiO}_{2}$ nanotubes in viscous electrolytes," Electrochimica Acta, vol. 52, no. 3, pp. 1258-1264, 2006.

[34] J. M. Macak, H. Hildebrand, U. Marten-Jahns, and P. Schmuki, "Mechanistic aspects and growth of large diameter selforganized $\mathrm{TiO}_{2}$ nanotubes," Journal of Electroanalytical Chemistry, vol. 621, no. 2, pp. 254-266, 2008.

[35] J. Yan and F. Zhou, " $\mathrm{TiO}_{2}$ nanotubes: structure optimization for solar cells," Journal of Materials Chemistry, vol. 21, no. 26, pp. 9406-9418, 2011.

[36] A. Ghicov and P. Schmuki, "Self-ordering electrochemistry: a review on growth and functionality of $\mathrm{TiO}_{2}$ nanotubes and other self-aligned $\mathrm{MO}_{x}$ structures," Chemical Communications, no. 20, pp. 2791-2808, 2009.

[37] S. Sreekantan, R. Hazan, and Z. Lockman, "Photoactivity of anatase-rutile $\mathrm{TiO}_{2}$ nanotubes formed by anodization method," Thin Solid Films, vol. 518, no. 1, pp. 16-21, 2009.

[38] C. A. Grimes, "Synthesis and application of highly ordered arrays of $\mathrm{TiO}_{2}$ nanotubes," Journal of Materials Chemistry, vol. 17, no. 15, pp. 1451-1457, 2007.

[39] P. Roy, S. Berger, and P. Schmuki, “ $\mathrm{TiO}_{2}$ nanotubes: synthesis and applications," Angewandte Chemie, vol. 50, no. 13, pp. 29042939, 2011.

[40] K. S. Raja, M. Misra, and K. Paramguru, "Formation of self-ordered nano-tubular structure of anodic oxide layer on titanium," Electrochimica Acta, vol. 51, no. 1, pp. 154-165, 2005.
[41] C. W. Lai and S. Sreekantan, "Comparison of photocatalytic and photoelectrochemical behavior of $\mathrm{TiO}_{2}$ nanotubes prepared by different organic electrolyte," Optoelectronics and Advanced Materials: Rapid Communications, vol. 6, no. 1-2, pp. 82-86, 2012.

[42] V. K. Mahajan, M. Misra, K. S. Raja, and S. K. Mohapatra, "Selforganized $\mathrm{TiO}_{2}$ nanotubular arrays for photoelectrochemical hydrogen generation: effect of crystallization and defect structures," Journal of Physics D: Applied Physics, vol. 41, no. 12, Article ID 125307, 2008.

[43] H.-J. Kim and K.-H. Lee, "Dependence of the morphology of nanostructured titanium oxide on fluoride ion content," Electrochemical and Solid-State Letters, vol. 12, no. 3, pp. C10C12, 2009.

[44] C. W. Lai and S. Sreekantan, "Photoelectrochemical performance of smooth $\mathrm{TiO}_{2}$ nanotube arrays: effect of anodization temperature and cleaning methods," International Journal of Photoenergy, vol. 2012, Article ID 356943, 11 pages, 2012.

[45] H. Yang and C. Pan, "Diameter-controlled growth of $\mathrm{TiO}_{2}$ nanotube arrays by anodization and its photoelectric property," Journal of Alloys and Compounds, vol. 492, no. 1-2, pp. L33-L35, 2010.

[46] P.-C. Chen, S.-J. Hsieh, C.-C. Chen, and J. Zou, "Fabrication and characterization of chemically sensitive needle tips with aluminum oxide nanopores for $\mathrm{pH}$ indication," Ceramics International, vol. 39, no. 3, pp. 2597-2600, 2013.

[47] K. Yasuda, J. M. Macak, S. Berger, A. Ghicov, and P. Schmuki, "Mechanistic aspects of the self-organization process for oxide nanotube formation on valve metals," Journal of the Electrochemical Society, vol. 154, no. 9, pp. C472-C478, 2007.

[48] L. V. Taveira, J. M. Macák, H. Tsuchiya, L. F. P. Dick, and P. Schmuki, "Initiation and growth of self-organized $\mathrm{TiO}_{2}$ nanotubes anodically formed in $\mathrm{NH}_{4} \mathrm{~F} /\left(\mathrm{NH}_{4}\right)_{2} \mathrm{SO}_{4}$ electrolytes," Journal of the Electrochemical Society, vol. 152, no. 10, pp. B405B410, 2005.

[49] A. Elsanousi, J. Zhang, H. M. H. Fadlalla et al., "Self-organized $\mathrm{TiO}_{2}$ nanotubes with controlled dimensions by anodic oxidation," Journal of Materials Science, vol. 43, no. 22, pp. 7219-7224, 2008.

[50] B. G. Lee, J. W. Choi, S. E. Lee, Y. S. Jeong, H. J. Oh, and C. S. Chi, "Formation behavior of anodic $\mathrm{TiO}_{2}$ nanotubes in fluoride containing electrolytes," Transactions of Nonferrous Metals Society of China, vol. 19, no. 4, pp. 842-845, 2009.

[51] L. Sun, S. Zhang, X. Sun, and X. He, "Effect of the geometry of the anodized titania nanotube array on the performance of dyesensitized solar cells," Journal of Nanoscience and Nanotechnology, vol. 10, no. 7, pp. 4551-4561, 2010.

[52] Y. B. Liu, J. H. Li, B. X. Zhou et al., "Comparison of photoelectrochemical properties of $\mathrm{TiO}_{2}$-nanotube-array photoanode prepared by anodization in different electrolyte," Environmental Chemistry Letters, vol. 7, no. 4, pp. 363-368, 2009.

[53] L. Yang, Y. Xiao, S. Liu, Y. Li, Q. Cai, and S. Luo, "Photocatalytic reduction of $\mathrm{Cr}(\mathrm{VI})$ on $\mathrm{WO}_{3}$ doped long $\mathrm{TiO}_{2}$ nanotube arrays in the presence of citric acid," Applied Catalysis B: Environmental, vol. 94, p. 142, 2010. 

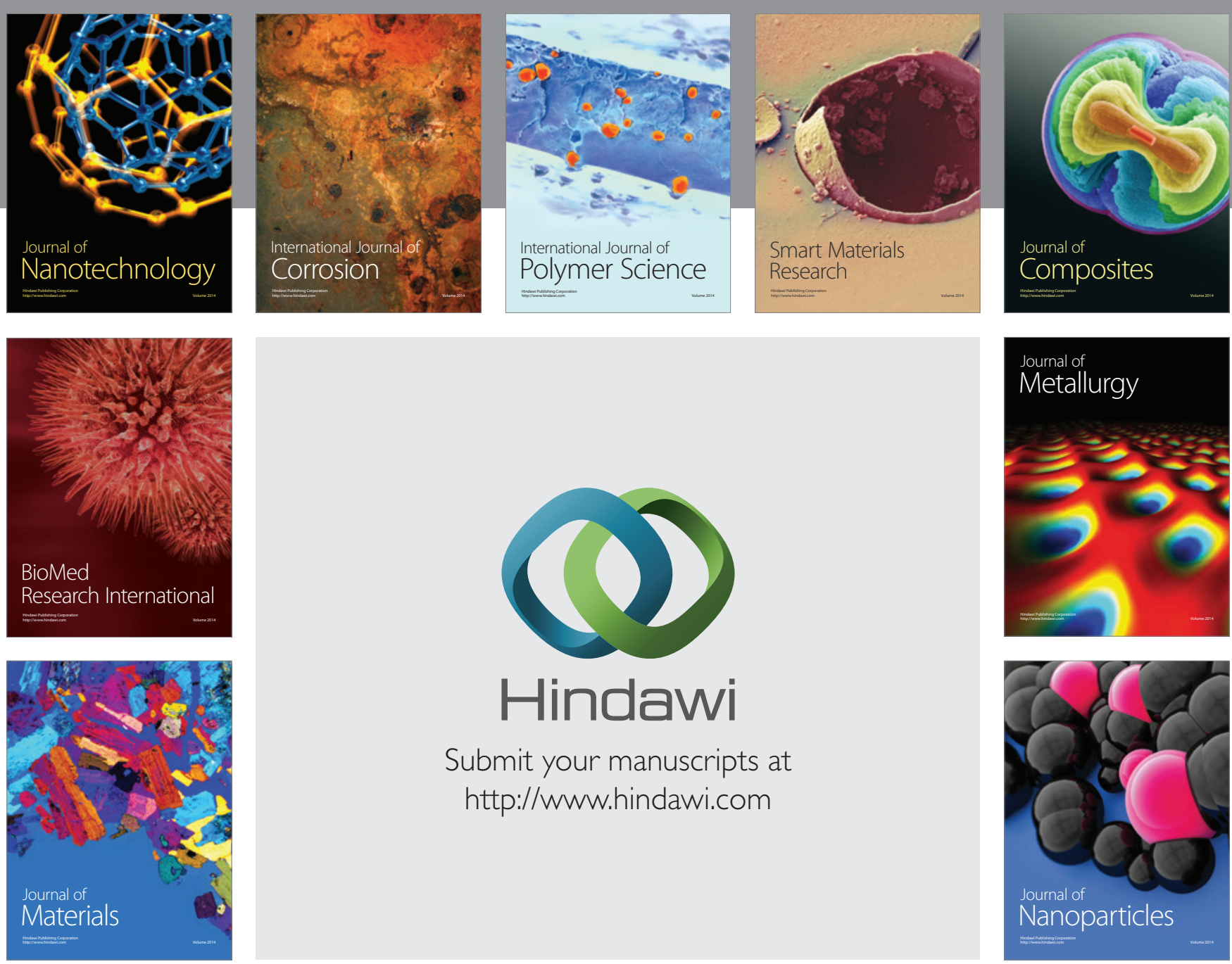

Submit your manuscripts at http://www.hindawi.com
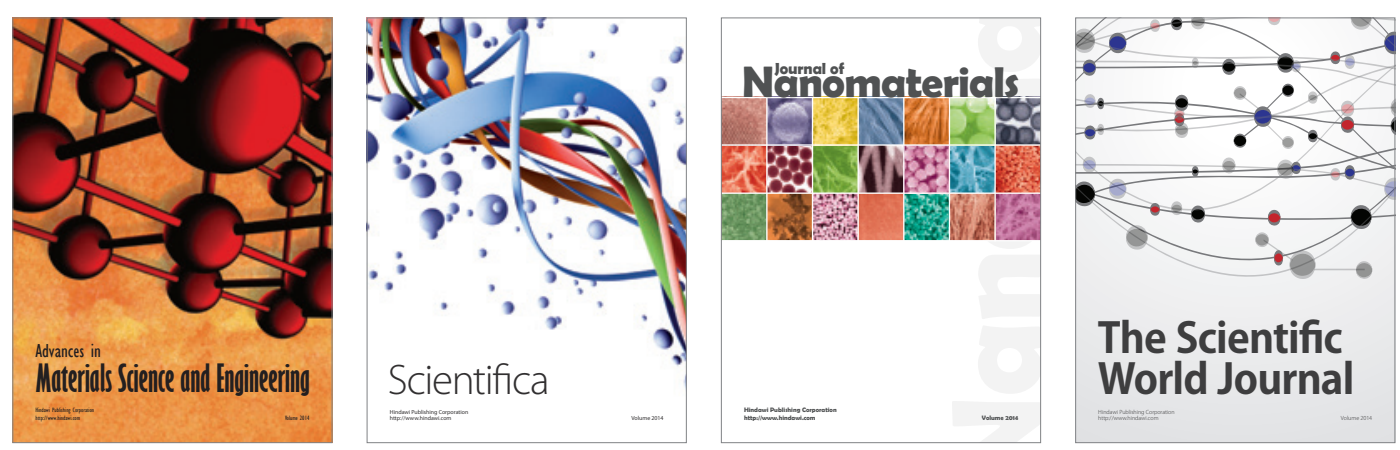

\section{The Scientific World Journal}
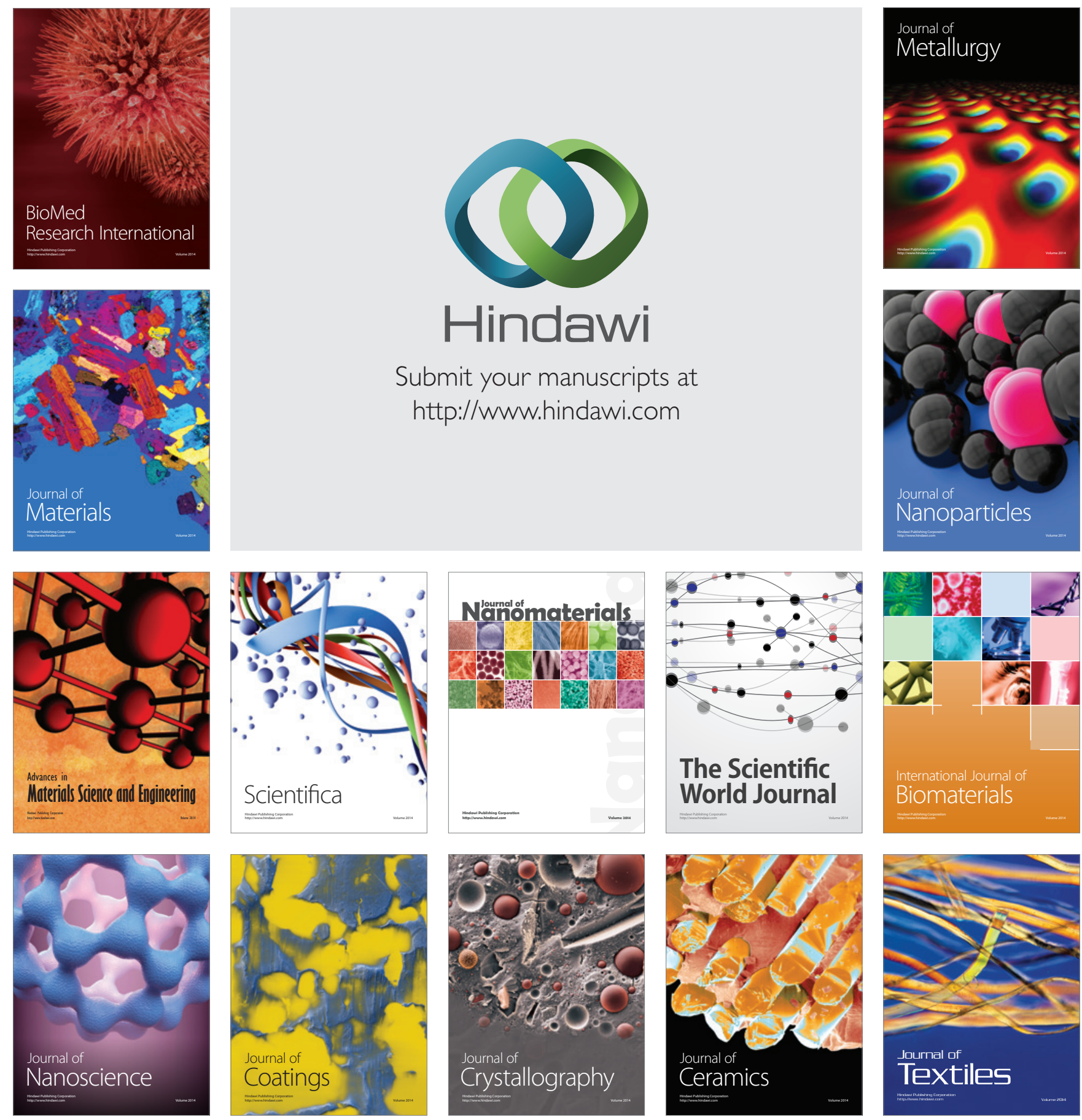